\title{
Perkembangan Keterampilan Sosial Anak Usia Dini
}

\author{
Selly Puspa Dewi Rachman ${ }^{1}$, Isah Cahyani ${ }^{2}$ \\ ${ }^{1}$ Lembimjar Neutron Bandung 4 \\ Jl. Terusan Jakarta No. 19 Kiara Condong, Bandung, Jakarta \\ ${ }^{2}$ Universitas Pendidikan Indonesia \\ Jl. Dr. Setiabudhi No. 229 Bandung, Indonesia \\ Email: sellypuspa@gmail.com ${ }^{1}$, isahcahyani@gmail.com²
}

Naskah diterima: 12 November 2018, direvisi: 20 Februari 2019, diterbitkan: 30 Maret 2019

\begin{abstract}
Abstrak
Keterampilan sosial merupakan keterampilan yang membantu individu untuk berinteraksi dan berkomunikasi dengan orang lain baik secara verbal maupun nonverbal. Keterampilan sosial anak usia dini perlu diidentifikasi sejak awal untuk mencegah perilaku negatif. Oleh sebab itu, penelitian ini bertujuan untuk mengidentifikasi perkembangan keterampilan sosial anak usia dini. Merujuk pada tujuan penelitian, pendekatan kualitatif dengan metode studi kasus dipilih sebagai metode penelitian. Sebanyak 10 anak usia dini dengan rentang usia 3-4 tahun serta guru kelas terpilih sebagai partisipan penelitian. Penelitian berlokasi di salah satu PAUD kecamatan Lembang. Data terkumpul melalui observasi, wawancara, serta studi dokumentasi. Adapun validasi data menggunakan teknik triangulasi sedangkan data teranalisis melalui analisis tematik. Hasil penelitian mengindikasikan adanya keterampilan sosial pada anak usia dini. Hal ini membuktikan bahwa anak usia dini memiliki perkembangan keterampilan sosial. Berkembangnya keterampilan anak usia dini dipengaruhi oleh lingkungan terutama guru dan orang tua.
\end{abstract}

Kata kunci: anak usia dini, keterampilan sosial, perkembangan.

\begin{abstract}
Social skills are learned behaviors that help individual to interact and communicate with others, both verbally and nonverbally. Early childhood social skills have to identified earlier to prevent the negative behavior. So, the aim of this research is to identified the development of early childhood social skills. Case study research with qualitative approach are used and the research subjects are ten children $(3-4$ years old) and a teacher class. This research located at one of early childhood education in Lembang Subdistrict. Data collection technique would be used observation, interview, and study of document. Meanwhile, the data were validated and analyzed by triangulation technique and thematic analysis. Result of this research indicated that early childhood showed social skills. The result approved that early childhood already have social skills. The development of early childhood social skills were effected by environment including teacher and parents.
\end{abstract}

Keywords: development, early chilhood, social skills. 


\section{Pendahuluan}

Pada awal kehidupan, setiap anak akan mengalami berbagai pengalaman. Pengalaman-pengalaman tersebut memberikan dampak pada perkembangan otak bagian depan. Otak bagian depan memproses perasaan dan interaksi sosial. Oleh karena itu, otak depan berperan penting selama masa emas anak. Masa emas anak terjadi pada usia dini, yaitu lima tahun pertama kehidupannya (Mashar, 2011, hlm. 10).

Usia dini terjadi ketika anak memulai untuk mengembangkan kemampuan sosial yang memengaruhi kesehatan mental dan fisiknya pada masa sekarang dan mendatang. Masa anak usia dini sering disebut dengan masa bermain. Hal ini dikarenakan anak usia dini memiliki porsi yang lebih banyak untuk bermain. Terdapat sebutan lain untuk anak usia dini, yaitu usia prasekolah, usia berkelompok, usia menjelajah, dan usia kreatif (Mashar, 2011).

Allen \& Marotz (2010) mengklasifikasikan anak usia dini dimulai dari usia 3-8 tahun. Berbeda dengan UU Nomor 20 Tahun 2003 tentang Sistem Pendidikan Nasional, di mana anak usia dini dimulai sejak lahir hingga usia enam tahun. Penelitian ini memfokuskan pada anak-anak yang berusia 3-4 tahun. Berdasarkan delapan tahap perkembangan psikososial Erik Erikson, anak berumur 3-5 tahun berada dalam tahap tiga, yaitu initiative vs guilt (Riyadi, 2011).

Pada tahap ini, anak akan membuat pilihan mengenai karakteristik orang lain berdasarkan identifikasi orang tuanya. Anak cenderung bertingkah laku yang bersifat mengganggu orang dewasa karena ia memiliki rasa keingintahuan yang tinggi. Bimbingan dari orang dewasa sangat dibutuhkan pada masa ini. Hal tersebut bertujuan agar pengetahuan awal yang diterima anak bersifat positif (Mutiah, 2012).

Anak usia dini berada pada masa peka karena secara tidak disadari terjadi pematangan fisik dan psikis. Oleh karena itu, dibutuhkan stimulasi yang sesuai dengan kebutuhan anak. Pada usia ini juga anak akan belajar melalui permainan (Mutiah, 2012).

Setiap anak akan memelajari dasar perilaku sosial. Anak akan menjelajah untuk mencari tahu kondisi lingkungan sekitarnya. Selain berada di masa peka, anak usia dini juga berada pada masa usia emas. Masa emas anak terjadi pada usia dini, yaitu lima tahun pertama kehidupannya (Mashar, 2011).

Hasil penelitian Osborn, White, \& Bloom (dalam Mutiah, 2012 hlm. 3) menerangkan bahwa, "sekitar 50\% kecerdasan orang dewasa sudah dimiliki oleh anak berusia empat tahun. Peningkatan 30\% selanjutnya terjadi pada usia 8 tahun serta $20 \%$ sisanya terjadi pada pertengahan atau akhir dasawarsa kedua”. 
Semua kegiatan yang terjadi pada kehidupan awal anak sangat berharga dan menentukan masa depannya. Hal tersebut berkaitan dengan stimulasi dan respons yang diberikan. Menurut Skinner (2013, hlm. 75), "stimulus merupakan agen eksternal di mana perilaku yang dikendalikannya disebut respons". Suatu respons dapat diukur sebagai fungsi dari intensitas stimulus.

Hendaknya, orang dewasa memberikan stimulus kepada anak pada setiap masa yang akan dilewatinya. Mutiah (2010, hlm. 7) menuliskan lima masa yang dihadapi oleh setiap anak, yaitu masa peka, masa egosentris, masa berkelompok, masa meniru, dan masa eksplorasi.

\section{Masa peka}

Masa peka merupakan masa yang sensitif dalam penerimaan stimulasi dari lingkungan. KidsMatter Early Childhood (2010) menjelaskan bahwa interaksi adalah kunci dari keterampilan hidup manusia.

\section{Masa egosentris}

Manusia memiliki ego yang tinggi. Ego tersebut secara perlahan akan dapat dikontrol seiring dengan berjalannya waktu. Namun, orang dewasa tidak dapat memaksakan kehendaknya terhadap ego dari seorang anak usia dini. Anak usia dini selalu menginnginkan kemauannya dikabulkan. Hal ini membutuhkan kesabaran dan perhatian dari orang dewasa.

\section{Masa berkelompok}

Anak-anak lebih memilih untuk bermain secara berkelompok karena dapat merasakan kesenangan yang lebih besar dibandingkan dengan bermain sendiri. Ia akan mencari teman sebayanya. Ketika bermain, secara tidak disadari anak akan melakukan proses seleksi. Proses seleksi itu dilakukan untuk memilih hal-hal yang sesuai dengan kepribadiannya. Hal yang perlu dilakukan oleh orang dewasa adalah memberikan kesempatan pada anak untuk bermain bersama.

\section{Masa meniru}

Tingkah laku anak di masa yang akan datang merupakan cerminan dari perilaku yang ditirunya sewaktu dini. Sebagai bagian dari pembelajarannya, anak akan melakukan pengamatan dan peniruan terhadap perilaku yang ia dapatkan dari lingkungan sekitar. Oleh karena itu, yang perlu orang dewasa lakukan adalah memberikan contoh yang baik ketika sedang bersama anak usia dini. Hal tersebut dilakukan untuk mencegah sesuatu yang tidak diinginkan dikemudian hari.

\section{Masa eksplorasi}


Masa eksplorasi disebut juga sebagai masa penjelajahan. Pengetahuan yang dimiliki oleh anak usia dini belum banyak. Oleh karena itu, ia senang untuk pergi kesana kemari demi mendapatkan pengetahuan baru. Ia akan memanfaatkan benda-benda yang berada disekitarnya dan melakukan trial and error terhadap benda-benda yang ditemukannya.

Penelitian ini difokuskan pada anak yang berusia 3-4 tahun sehingga akan dibahas perkembangan anak yang berusia 3-4 tahun saja. Meskipun mereka berada di sekolah yang sama akan tetapi mereka tidak mengalami perkembangan yang serupa. Sekalipun kembar identik, tidak akan ditemukan sifat yang sama persis diantara mereka. Pada dasarnya, manusia bersifat unik sehingga tidak ada kesamaan yang pasti dalam diri manusia.

Kestenbaum \& Gelman (dalam Papalia, Old, \& Feldman, 2010, hlm. 369) mengisyaratkan bahwa, "perkembangan yang terjadi pada anak usia 3 tahun, ia akan memahami mengenai perasaan bahagia dan sedih yang disebabkan oleh pemberian hadiah". Namun, masih belum dapat memahami secara penuh mengenai emosi diri sendiri.

Anak usia 3 tahun sering sekali merasa bingung akan emosinya. Ketika ia senang mendapatkan hadiah tetapi bentuk atau warnanya tidak sesuai dengan yang diinginkan. Disatu sisi ia bahagia tapi di sisi lain ia kecewa atau sedih.

Berbeda dengan anak yang berada pada usia 4-5 tahun. Mereka belum mengetahui arti bangga. Anak usia 4-5 tahun tidak akan mengatakan apakah orang tuanya bangga atau malu terhadapnya atau tidak. Ranah emosi anak usia 4 tahun masih berada dalam kategori labil. Namun, sifat pemarah mulai perlahan hilang dari diri anak perempuan dan tetap berada dalam diri anak laki-laki (Papalia, Old, \& Feldman, 2010).

Hakikatnya, anak usia 3-5 tahun penuh energi, antusiame, dan rasa ingin tahu. Anak usia tiga tahun cenderung tenang, sedangkan anak usia empat tahun tidak ada kata lelah untuk segala aktivitasnya. Berbeda juga dengan anak usia lima tahun yang rasa percaya dirinya semakin tinggi.

Manusia merupakan makhluk sosial. Hal tersebut mamiliki arti bahwa manusia tidak dapat hidup sendiri. Manusia memiliki ketergantungan terhadap makhluk hidup lainnya. Oleh karena itu, manusia dituntut memiliki keterampilan sosial yang dapat menjadikannya bagian dari sebuah kelompok. Anak usia dini mengembangkan keterampilan sosial melalui interaksi dengan guru, bekerja sama dalam pembelajaran, bermain dengan teman, dan berinteraksi dengan orang sekitarnya di dalam kelas maupun di luar kelas (Semrud-Clikeman, 2007).

Keterampilan sosial merupakan keterampilan yang membantu individu untuk berinteraksi dan berkomunikasi dengan orang lain baik secara verbal maupun nonverbal 
(Gresham \& Elliott dalam Angacian, dkk., 2015). Sementara itu, Elliot, Malecki, \& Demaray (2001) mengisyaratkan keterampilan sosial sebagai keterampilan yang penting dimiliki oleh individu untuk mencapai kesuksesan dalam kehidupan sosial dan akademik serta dapat memegang peran penting dalam pencegahan perilaku negatif.

Keterampilan sosial yang dimaksud dapat dipelajari dan dikembangkan melalui pengalaman sehari-hari. Pada dasarnya, bersosialisasi dengan orang lain merupakan kunci keterampilan hidup. Makhluk hidup mengalami perkembangan selama masa hidupnya. Tiga ranah utama perkembangan manusia adalah fisik, kognitif, dan psikososial (Papalia, Old, \& Feldman, 2010).

Pada masa kanak-kanak, interaksi sosial membantu perkembangan tiga ranah utama (Vygotsky dalam Papalia, Old, \& Feldman. 2010, hlm. 56). Kemampuan manusia tidak berkembang dengan sendirinya. Meskipun demikian, perkembangan yang terjadi mengarah kepada hal yang lebih matang dan positif.

Salah satu keterampilan manusia yang berkembang adalah keterampilan sosial. Keterampilan sosial adalah perilaku yang terdiri dari interaksi positif dengan orang lain dan lingkungan (Lynch \& Simpson, 2010). Penanaman konsep keterampilan sosial dapat dilakukan sedari dini. Maryani (2011, hlm. 18) menyatakan bahwa, "keterampilan sosial adalah keterampilan untuk berinteraksi dalam lingkungan".

Berbicara mengenai aspek keterampilan sosial, menurut Vayrynen, dkk. (2016) terdapat empat dimensi dalam keterampilan sosial yang meliputi empati, toleransi, kerja sama, dan perilaku adaptif. Empati dan toleransi merupakan dimensi keterampilan sosial yang berkaitan dengan perasaan dan sikap. Sementara itu, kerja sama dan perilaku adaptif merupakan dimensi keterampilan yang erat berkaitan dengan perilaku.

Anak yang dapat melewati hari di sekolah sesuai dengan tingkat perkembangannya dapat dikategorikan memiliki keterampilan sosial yang cukup berkembang. Anak dapat menjawab pertanyaan guru, bergabung dengan teman, merapikan kembali peralatan belajar atau mainan, atau buang air kecil tanpa ditemani menunjukkan adanya keterampilan sosial.

Di sisi lain, beberapa anak tidak menunjukkan perilaku yang sesuai dengan tingkat perkembangannya (Arnesen, dkk., 2017). Sejumlah anak lebih senang menyendiri, mudah emosi, dan senang mengganggu teman tanpa sebab. Perilaku anak yang demikian terkadang dianggap sebagai perilaku yang wajar karena orang tua maupun guru menganggap hal tersebut bagian dari masa perkembangan. Ada juga yang menganggap kesenjangan perilaku pada anak 
merupakan hal yang kurang wajar tetapi tidak ada upaya untuk mengatasi kesenjangan yang terjadi (Merrell, 2002).

Merujuk pernyataan tersebut, maka guru perlu melakukan identifikasi awal terhadap perilaku siswa sebagai upaya mencegah perilaku negatif yang dapat berdampak pada kehidupan sosial serta pencapaian akademik anak. Apabila guru sudah mengidentifikasi perilaku sejak awal maka akan lebih mudah untuk menangani suatu masalah (Elliot, Huai, \& Roach, 2007; Lane, Oakes, \& Menzies, 2010).

Berdasarkan penjelasan di atas, maka peneliti tertarik untuk meneliti perkembangan keterampilan sosial anak usia dini. Penelitian ini bertujuan untuk mengidentifikasi perkembangan keterampilan sosial anak usia dini. Adapun manfaat diadakannya penelitian ini yaitu membantu orang tua serta guru untuk mengenali perkembangan keterampilan sosial anak usia dini sehingga dapat memberi beragam intervensi sebagai upaya pencegahan perilaku negatif.

\section{Metodologi}

Pendekatan kualitatif dengan metode studi kasus terpilih untuk menjawab rumusan masalah. Penelitian kualitatif dilakukan dengan tujuan untuk mengeksplor sebuah fenomena. Studi kasus ditentukan oleh minat pada kasus-kasus individual bukan ditentukan oleh metode-metode penelitian yang digunakan (Stake, 2009, hlm. 299).

Partisipan dalam penelitian ialah 10 anak usia dini yang tergabung dalam kelompok kecil di salah satu PAUD. Sepuluh anak usia dini yang menjadi partisipan berada dalam rentang usia 3-4 tahun. Selain itu, guru kelompok kecil juga menjadi partisipan dalam penelitian. Tempat penelitian terletak di satu PAUD kecamatan Lembang.

Teknik pengumpulan data dalam penelitian menggunakan observasi, wawancara, serta studi dokumentasi. Observasi merupakan proses pengumpulan informasi yang bersifat terbuka (Creswell, 2015). Observasi yang akan dilakukan pada penelitian ini adalah observasi partisipatif. Peneliti mengunjungi lokasi penelitian dan membuat catatan serta terlibat dalam kegiatan subjek penelitian. Hal ini memudahkan peneliti dalam mendapatkan informasi yang lebih mendalam mengenai kejadian yang terjadi.

Wawancara merupakan kegiatan tanya jawab yang dilakukan untuk mendapatkan informasi dari narasumber. Dalam penelitian kualitatif, wawancara terjadi ketika peneliti menanyakan berbagai pertanyaan yang bersifat terbuka (Neumann, 2014). Wawancara 
terbuka disarankan dilakukan dalam penelitian kualitatif agar para subjek penelitian mengetahui bahwa ia sedang diwawancarai dan memahami maksud serta tujuan peneliti.

Studi dokumentasi bermanfaat untuk mendukung hasil observasi atau wawancara. Dokumentasi dalam penelitian ini menggunakan foto. Foto dapat menjadi salah satu bukti yang otentik. Foto menghasilkan data deskriptif. Penggunaan foto untuk melengkapi sumber data memiliki manfaat namun perlu diberikan catatan khusus mengenai keadaan yang terjadi dalam foto tersebut (Moeloeng, 2011).

Analisis data menggunakan analisis tematik. Naughton \& Hughes (2009) menyatakan bahwa analisis tematik merupakan teknik analisis data yang dilakukan dengan cara melihat dan menemukan tema-tema dan kategori yang diperoleh dalam data yang telah dikodekan terlebih dahulu. Tahapan analisis data dalam penelitian ini meliputi (1) menyiapkan data mentah; (2) melakukan pengkodean (coding); (3) klasifikasi kode; (4) penafsiran data; (5) penyajian data (Creswell, 2013).

Sementara itu, validitas data menggunakan triangulasi. Triangulasi merupakan suatu proses pemanfaatan persepsi yang beragam untuk mengklarifikasi makna, memverifikasi kemungkinan pengulangan dari suatu observasi atau interpretasi dengan prinsip tidak ada observasi dan interpretasi yang dapat diulang (Denzin \& Lincoln, 2009). Triangulasi merujuk pada pengumpulan informasi sebanyak mungkin dari berbagai sumber melalui berbagai metode (Cohen, Manion, \& Marison, 2011). Penelitian ini menggunakan triangulasi jenis data yang diperoleh dari catatan lapangan, hasil wawancara, dan analisis dokumen. Selain itu, triangulasi sumber dilakukan kepada guru dan anak usia dini.

\section{Hasil dan Diskusi}

Dimensi keterampilan sosial yang diamati mengacu pada pendapat Vayrynen, dkk. (2016) berupa empati, toleransi, kerja sama, dan perilaku adaptif. Kerja sama muncul ketika anak bermain dengan alat permainan edukatif seusai belajar. Anak-anak tampak bekerja sama untuk membangun gedung dengan menggunakan balok. Kemudian, anak bermain peran untuk menjaga gedung dari serangan musuh.

Setelah lelah bermain, guru mengajak anak untuk membereskan alat permainan. Anak-anak menunjukkan kerja sama saat membereskan alat permainan. Dalam situasi tersebut, tidak ada anak yang diam. Semua ikut merapikan kembali alat permainan dan menyimpan di tempat yang telah tersedia. 
Munculnya sikap kerja sama anak tidak terlepas dari arahan guru. Guru mengembangkan sikap kerja sama dengan melibatkan diri dalam kegiatan anak sehingga anak termotivasi untuk merapikan alat permainan. Hal tersebut dikuatkan berdasarkan wawancara yang dilakukan peneliti kepada guru kelas kecil. Menurut Ibu DS, anak-anak biasanya tidak merapikan dan menyimpan mainan kembali sesudah bermain. Anak-anak perlu diajarkan tanggung jawab serta kerja sama. Anak-anak tidak bisa diperintah begitu saja tetapi kita orang dewasa harus memberi contoh sehingga anak tidak merasa diperintah dan merapikan mainan dengan hati senang.

Selanjutnya, sikap kerja sama muncul ketika anak-anak beraktivitas di luar ruangan. Guru mengajak anak untuk bermain bowling dengan menggunakan botol serta bola plastik. Ketika guru sedang menata botol, dua anak mendekati guru dan ikut menata botol. Dua anak berinisial LO dan SD juga ikut memasukkan botol ke dalam wadah seusai permainan. Selain itu, sikap kerja sama tampak seusai kegiatan belajar. Anak-anak bekerja sama merapikan kursi dan membersihkan ruangan dari sampah (bekas guntingan atau serutan).

Personal living skills diperlihatkan anak ketika selesai belajar. Anak-anak dapat merapikan alat tulisnya sendiri tanpa diinstruksikan guru. Anak-anak segera memasukkan alat tulisnya ke dalam tas. Selain itu, anak berinisial FL dan TR menunjukkan kemandirian saat buang air kecil tidak diantar oleh guru.

FL dan TR menolak tawaran guru untuk mengantarnya ke kamar mandi. Anak-anak menyimpan sepatu di rak dan mengeringkan kaki tanpa instruksi guru. Anak-anak juga sudah memiliki kesadaran akan mencintai lingkungan. Hal ini dibuktikan anak ketika membuang sampah pada tempatnya.

Anak berinisial LS juga memperlihatkan personal living skills yang baik. LS dapat menjaga kebersihan dirinya. LS mengeluarkan dan merapikan kembali kotak bekal yang dibawa. Kemudian, LS mencuci serta mengeringkan tangan dengan tisu tanpa bantuan guru. Merujuk pada hasil pengamatan yang telah dilakukan, maka peneliti menyimpulkan bahwa personal living skills sudah tampak dalam diri anak usia dini.

Social living skills tampak ketika anak dapat menjawab sapaan guru, menyapa guru terlebih dahulu, dan menyapa teman. Selama pengamatan, peneliti menemukan anak yang bersikap sangat sopan ketika meminjam mainan teman.

Anak berinisial ZD dan ZY selalu mengucapkan kata tolong ketika meminta bantuan dan meminjam krayon. Sesudah memperoleh bantuan ZD dan ZY mengucapkan terima kasih kepada teman. Namun, ada juga anak yang kurang berbicara sopan sehingga guru harus 
menegur anak tersebut secara halus. Hal ini sangat mungkin terjadi karena anak usia dini senang menjadikan kata baru sebagai lelucon.

Bersumber pada observasi, wawancara, serta studi dokumentasi maka peneliti menemukan keterampilan sosial yang berkembang pada anak usia dini usia 3-4 tahun yaitu kerja sama dan perilaku adaptif.

\section{Pembahasan}

Dimensi keterampilan sosial pertama yang muncul yaitu kerja sama. Kerja sama adalah keterlibatan mental dan emosional individu di dalam situasi kelompok yang mendorong mereka untuk memberikan kontribusi dan tanggung jawab dalam mencapai tujuan kelompok (Caughy, dkk., 2011).

Tujuan kerja sama bagi anak usia dini yaitu membentuk kepribadian anak agar dapat mengembangkan keterampilan berkomunikasi dan bekerja sama dengan orang lain dalam berbagai situasi, memantapkan interaksi pribadi antara anak dengan teman sebaya atau guru, serta membangun proses sosial (Hess, dkk., 2013).

Berkaitan dengan sikap kerja sama yang muncul dalam diri anak, peran guru tidak terlepas dari pembentukan sikap. Guru memberikan contoh yang dapat ditiru anak dengan mudah. Guru mau terlibat secara langsung dalam pembentukan sikap kerja sama.

Menurut Rouse \& Floriand (2012) kerja sama dalam diri anak usia dini sangat mudah terbentuk apabila orang sekitar menunjukkan sikap yang sama. Dalam hal ini, seorang guru tidak diperkenankan hanya memberi instruksi tetapi ikut bergabung dengan anak. Senada dengan itu, Goodman \& Burton (2010) menyatakan bahwa guru ialah sosok yang menjadi teladan anak sehingga peran guru sangat penting untuk membangun keterampilan sosial.

Penelitian dari Jennings \& DiPrete (2010) dan Iruka, Burchinal, \& Cai (2010) membuktikan bahwa guru memberikan dampak terhadap keterampilan sosial siswa yang berimbas pada pencapaian akademik. Dampak terhadap keterampilan sosial siswa lebih besar jika dibandingkan dengan pengembangan akademik siswa. Keterampilan sosial memiliki dampak positif terhadap perkembangan kemampuan akademik pada jenjang awal sekolah dasar.

Dimensi keterampilan sosial kedua yang muncul yaitu perilaku adaptif. Perilaku adaptif adalah kematangan diri dan sosial individu untuk melakukan kegiatan umum sehari- 
hari sesuai dengan usia dan berkaitan dengan budaya kelompoknya (Delphie, 2009). Perilaku adaptif terbagi ke dalam dua jenis yang meliputi personal living skills dan social living skills.

Personal living skills adalah perilaku adaptif yang ditunjukkan dengan kemandirian individu untuk mengelola dirinya sendiri seperti kemandirian dalam makan, berpakaian, dan merawat diri. Sementara itu, social living skills adalah kemampuan yang dimiliki individu untuk bermasyarakat seperti kemampuan membangun interaksi dengan teman atau orang dewasa, bertingkah memerhatikan tata krama, dan kemampuan berpartisipasi dalam kelompok (Delphie, 2009).

Personal living skills muncul ketika anak memperoleh stimulasi dari pihak yang sering terlibat dalam kehidupannya seperti guru dan orang tua. Sebagai upaya menerapkan pembelajaran yang sudah diajarkan, guru selalu menulis catatan kepada orang tua melalui buku penghubung. Buku penghubung bertujuan agar guru dapat menyampaikan perkembangan anak serta meminta dukungan orang tua untuk turut serta dalam pembentukan keterampilan sosial anak.

Hal ini selaras dengan hasil penelitian Tsangaridou, dkk. (2015) yang membuktikan bahwa keterampilan sosial anak berkembang lebih baik ketika guru dengan orang tua bekerja sama. Guru menyampaikan informasi terkait perkembangan anak dan membantu orang tua untuk mengatasi permasalahan anak.

Sejalan dengan itu, Humphrey, dkk. (2011) mengemukakan bahwa anak usia dini sedang berada pada masa peniruan. Mereka kerap menirukan perkataan maupun tindakan yang baru serta menjadikan lelucon kata-kata yang kurang baik.

Anak usia dini sedang berada dalam masa berkembang dan mudah menyerap hal-hal baru yang ada di sekitarnya. Keterampilan sosial akan mudah terbentuk pada anak usia dini sehingga kegiatan pembelajaran di sekolah atau kelompok bermain fokus pada perkembangan keterampilan sosial.

Anak membentuk keterampilan sosial melalui pengalaman serta pengamatan sekitarnya. Oleh sebab itu, orang yang banyak terlibat dengan kehidupan anak sangat perlu memberi contoh perilaku yang berdampak pada pembentukan keterampilan sosial anak (Gregoriadis, Grammatikopoulos, \& Zachopoulou, 2013).

Orang tua dan guru ialah orang yang banyak terlibat dengan kehidupan anak. Orang tua dan guru perlu menyinkronkan pembelajaran agar anak termotivasi untuk berperilaku sesuai dengan usia dan norma. Tidak dipungkiri bahwa pendidikan dalam keluarga merupakan dasar dari pembentukan kepribadian (Freeman \& Munandar, 2000). Anak akan 
meniru apa yang dilakukan oleh orang tuanya sehingga pengaruh yang diberikan oleh keluarga sangat melekat pada diri anak.

Guru dan orang tua berkewajiban dalam mengajarkan keterampilan sosial. Banyak cara bagi anak untuk mempelajari keterampilan sosial. Salah satunya dengan mengamati orang lain dan melewati proses trial and error. Orang dewasa dituntut memberikan contoh yang baik. Ketika anak mengamati perilaku sekitar, orang dewasa senantiasa mengarahkannya.

Hal tersebut sesuai dengan teknik scaffolding yang dikemukakan oleh Vygotsky. Orang dewasa hendaknya membantu anak melewati ZPD (Zone of Proximal Development) (Papalia, Old, \& Feldman, 2010, hlm. 56). Selama mendapatkan bimbingan dari orang dewasa, anak akan belajar mengenai tanggung jawab akan perilakunya sendiri. Jika anak dibimbing dengan baik, maka keberhasilan akan didapat.

Keberhasilan dalam mengembangkan keterampilan sosial dapat diraih dalam berbagai cara. Orang tua dan orang dewasa lainnya dapat melakukan tiga hal yang membantu anak dalam mengembangkan keterampilan sosialnya. Tiga hal yang dirangkum dari KidsMatter Early Childhood (2010), yaitu berinteraksi tatap muka, bermain bersama, dan mendukung anak untuk mempelajari keterampilan hidup.

\section{Penutup}

Merujuk pada temuan penelitian yang telah diuraikan, maka peneliti membuat suatu simpulan bahwa keterampilan sosial sudah berkembang pada anak usia dini. Keterampilan sosial yang diperlihatkan anak usia dini berupa kerja sama dan perilaku adaptif.

Kerja sama adalah keterlibatan mental dan emosional individu di dalam situasi kelompok yang mendorong mereka untuk memberikan kontribusi dan tanggung jawab dalam mencapai tujuan kelompok. Sementara itu, perilaku adaptif adalah kematangan diri dan sosial individu untuk melakukan kegiatan umum sehari-hari sesuai dengan usia dan berkaitan dengan budaya kelompoknya. Perilaku adaptif terbagi ke dalam dua jenis yang meliputi personal living skills dan social living skills.

Anak membentuk keterampilan sosial melalui pengalaman serta pengamatan sekitarnya. Oleh sebab itu, orang tua dan guru memiliki peran penting dalam mengajarkan keterampilan sosial.

Berdasarkan simpulan yang telah dipaparkan, maka peneliti menyarankan kepada praktisi pendidikan untuk memberi banyak stimulasi pada anak usia dini agar keterampilan 
sosial anak meningkat. Keterampilan sosial merupakan keterampilan yang penting untuk dikembangkan di masa emas anak. Stimulasi dapat dilakukan melalui permainan yang diintegrasikan dalam pembelajaran.

\section{Daftar Pustaka}

Allen, K.E \& Marotz, L.R. 2010. Profil pengembangan anake prakelabiran bingga usia 12 tabun. Jakarta: Indeks.

Angacian, dkk. 2015. School-based intervention for social skills in children from divorced families. Journal of Applied School Psychology, 31 (4): 315-346.

Arnesen, A., dkk. 2017. Validation of the elementary social behaviour assessment: teacher ratings of students' social skills adapted to Norwegian, grades 1-6. Emotional and Behavioural Difficulties, $1: 1-16$.

Caughy, M. O. B, L. dkk. 2012. Social competence in late elementary school: Relationships to parenting and neighborhood context. Journal of Youth and Adolescence, 41:1613-1627.

Cohen, L., Manion, L., \& Morrison, K. 2011. Research methods in education 7th ed. Milton Park: Routledge.

Creswell, J.W. 2013. Research design: Pendekatan kualitatif, kuantitatif, dan mixed. Yogyakarta: Pustaka Pelajar.

Creswell, J. 2015. Riset pendidikan perencanaan, pelaksanaan, dan evaluasi riset kualitatif dan kuantitatif (edisi kelima). Yogyakarta: Pustaka Pelajar.

Delphie, B. 2009. Bimbingan perilaku adaptif anak dengan hendaya perkembangan fungsional. Tangerang: CV. Kompetenesi Terapan Sinergi Pustaka.

Denzin, N.K., \& Lincoln, Y.S. 2009. Handbook of qualitative research. Yogyakarta: Pustaka Pelajar.

Elliott, S. N., Huai, N., \& Roach, A.T. 2007. Universal and early screening for educational difficulties: Current and future approaches. Journal of School Psychology, 45 : 137-161

Elliott, S. N., Malecki, C. K., \& Demaray, M. K. 2001. New directions in social skills assessment and intervention for elementary and middle school students. Exceptionality, $9: 19-32$.

Freeman, J., \& Munandar, U. 2000. Cerdas dan cemerlang (Sumantri, B. \& Singgih, E., Trans). Jakarta: PT. Gramedia Pustaka Utama.

Goodman, R., \& Burton, D. 2010. The inclusion of students with besd in mainstream schools: Teachers' experiences of and recommendations for creating a successful inclusive environment. Emotional and Behavioural Difficulties, 15 (3) : 223-237.

Gregoriadis, A., Grammatikopoulos, V., \& Zachopoulou, E. 2013. Evaluating preschoolers' social skills: The impact of a physical education program from the parents' perspective. International Journal of Humanities and Social Science, 3, (10) : 40-51. 
Hess, M., dkk. 2013. The parent version of the preschool social skills rating system: psychometric analysis and adaptation with a german preschool sample. Journal of Psychoeducational Assessment, 32 (3) : 216-226.

Humphrey, N. 2011. Measures of social and emotional skills for children and young people: A systematic review. Educational and Psychological Measurement, 71 : 617-637.

Iruka, I.U., Burchinal, M., \& Cai. K. 2010. Long-term effect of early relationshipsfor African American children's academic and social development: An examination from kindergarten to fifth grade. Journal of Black Psychology, 36 (2) : 144-171

Jennings, J.L., \& DiPrete, T.A. 2010. Teacher effects on social and behavioral skills in early elemantary school. Sociology of Educaton, 83 (2) : 135-159.

KidsMatter Early Childhood. 2010. Getting along: Developing social skills in early childhood. [Online]. Diakses dari www.kidsmatter.edu.au

Lane, K. L., Oakes, W., \& Menzies, H. 2010. Systematic screenings to prevent the development of learning and behavior problems: Considerations for practitioners, researchers, and policy makers. Journal of Disability Policy Studies, 21: 160-172.

Lynch, S.A., \& Simpson, C.G. 2010. Social skills: Laying the foundation for success. Dimensions of Early Childhood, 38 (2) : 1-10.

Maryani, E. 2011. Pengembangan program pembelajaran IPS untuk peningkatan keterampilan sosial. Bandung: Alfabeta.

Mashar, R. 2011. Emosi anak usia dini dan strategi pengembangannya. Jakarta: Kencana.

Merrell, K. W. 2002. School social behavior scales. Baltimore, MD: Brookes.

Moeloeng, L.J. 2011. Metodologi penelitian kualitatif. Bandung: PT. Remaja Rosdakarya.

Mutiah, D. 2012. Psikologi bermain anak usia dini. Jakarta: Kencana.

Naughton, G.M., \& Hughes, P. 2009. Doing action research in early childhood studies: A step by step guide. USA: Open University Press.

Neumann, L. 2014. Social research methods: Qualitative and quantitative approaches seventh edition. UK: Pearson Education.

Papalia, D.E., Old. S.W. \& Feldman, R.D. 2010. Human development (Psikologiperkembangan edisi ke sembilan). (A.K. Anwar, Trans). Jakarta: Kencana.

Riyadi, A. R. 2011. Personality development. Bandung: Program S1 Pendidikan Guru Sekolah Dasar.

Rouse, M., \& Florian, L. 2012. Inclusive practice project: Final report. Aberdeen. SD: University of Aberdeen.

Semrud-Clikeman, M. 2007. Social competence in children. New York, NY: Springer Science Business Media LLC.

Skinner, B.F. 2013. Ilmu pengetahuan dan perilaku manusia (Maufur, Trans). Yogyakarta: Pustaka Pelajar.

Stake, R.E. 2009. Studi kasus. (Dariyatno, Fata, Abi \& Rinaldi, Trans.) In Denzin, N.K and Lincoln, Y.S (Eds.). 2009. Handbook of qualitative research. Yogyakarta: Pustaka Pelajar. 
Tsangaridou, N. 2015. Developing preschoolers' social skills through cross-cultural physical education intervention. Early Child Development and Care, 184 (11) : 1550-1565.

Undang-Undang Republik Indonesia Nomor 20 Tahun 2003 tentang Sitem Pendidikan Nasional.

Vayrynen, S., dkk. 2016. Finnish and Russian teachers supporting the development of social skills. European Journal of Teacher Education, 1: 1-16. 